\title{
MAKING SOAP FROM READILY AVAILABLE AGRICULTURAL AND HOUSEHOLD WASTES CAN INCREASE CLEANLESS IN RURAL AREA
}

Eugenia Lucas, Thomas Ciaglo (Kenneth Frost), Department of Natural Sciences and Mathematics, Dominican University of California, 50 Acacia Avenue, San Rafael, CA 94901-2298

\section{ABSTRACT}

In some areas of the world, soap is too expensive for many people to soap. In general, soap is malternative exists. They can make their own soda. However, caustic soda, too, may be difficult to find or too expensive. The aim of this project is to develop a process for making soap from readily inexpensive chemicals. By using this process, rural people can get the benefits of readily available, inexpensive soap.

Soap is made from animal fats or vegetable oils by saponification using strong base. The simple soaps can be isolated as cakes or bars, or it can deve used as water solution. Many reaction conditions were studied to reaction conditions that can be performed in a kitchen or a fireplace and The soaps from this project were characterized primarily using infrared spectroscopy and several other analytical techniques as well as tests to show their effectiveness.

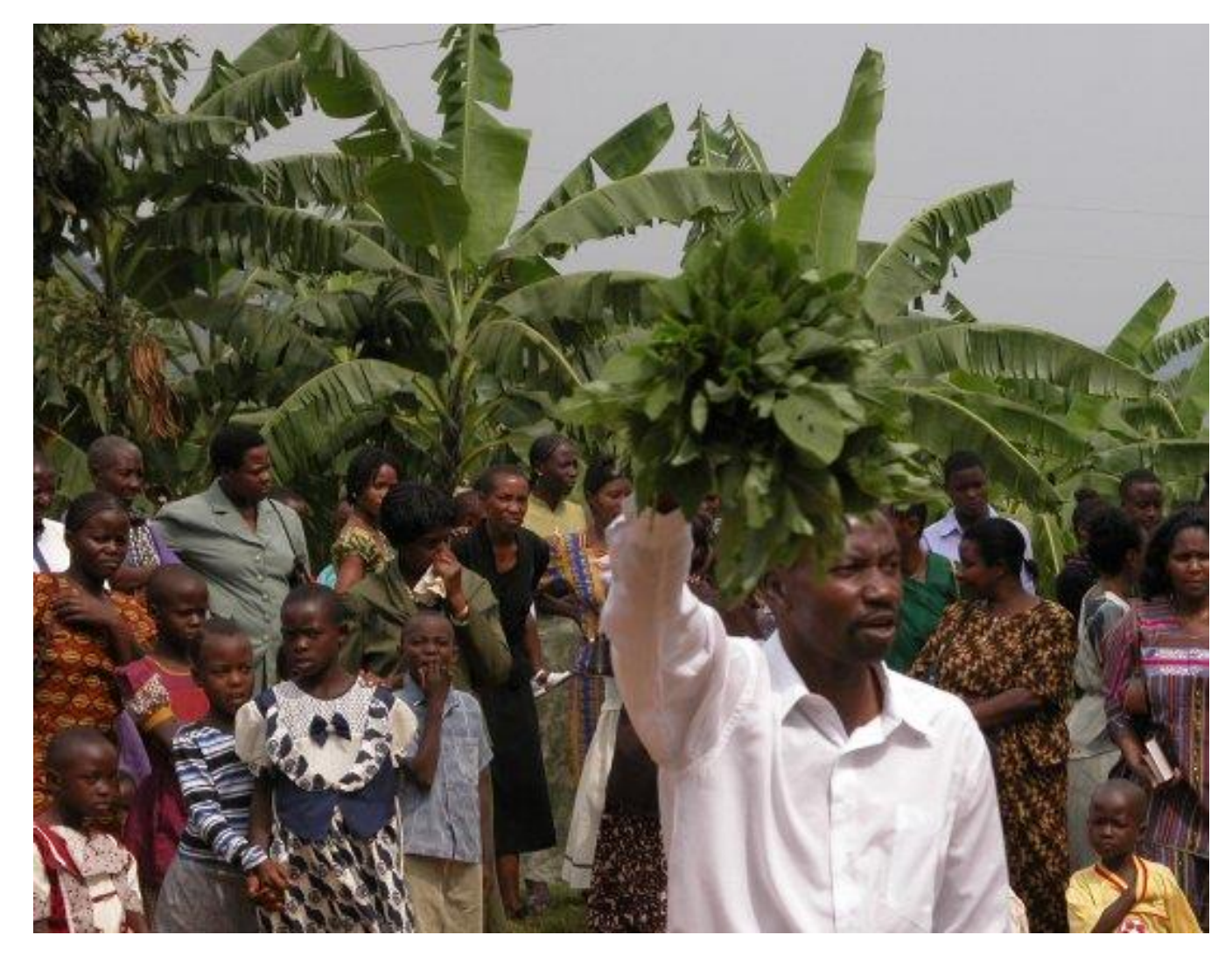

INTRODUCTION

Wutral parts $\mathrm{Or}$ weallhy countries and in many poor countries, soap is expensive and/or develop a process for making soap that could be shared with unsophisticated people, so that they could make their own soap. Although the tools used were typical chemical
laboratory equipment, the process could be easily adapted to a kitchen or even a fireplace. The most difificult challenge not yet addressed completely is the isolation of

\section{MATERIALS}

Distilled water or rain water, animal fats or vegetable oil, sodium hydroxide (NaOH) or ashes, scale for measuring the lye and fats, a large enamel or stainless steel saucepan, strong plastic or wooden spoon, a plastic rectangular container to be used

\section{METHOD FOR PREPARATION OF BASE FROM ASHES}

Preparing ashes; collect the unripe plantains peels, or bananas peels and dry them in
the sun, then dry them in the oven for three hours at $100 \mathrm{C}$ and let them cool. Place the peels in the open combustion pan and heat untili ignited. When heating, make sure to
mix them to ensure unitorm combustion. Heat until the ashes turn to a white gray color

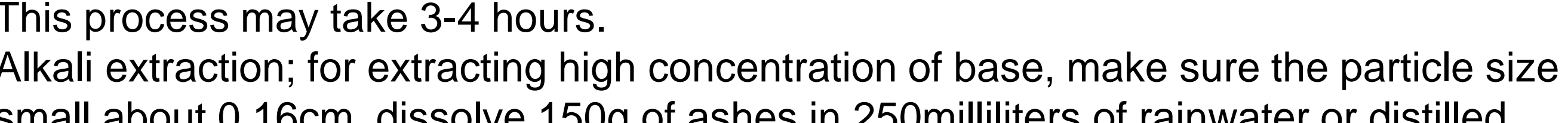
water. Heat the solution to $60 \mathrm{C}$ for eight hours or twelve hours. Cool and filter it to

obtain the basic extract.
Moles determin ation; titrate the filtered solution against $0.1 \mathrm{M} \mathrm{HCl}$ by using
phenolphthein indicator Obtain the spectronhototometer analysis of the extracted solution by using atomic absorption spectrophotometer. (See table 1 for data)
GENERAL REACTION

When fats or oils are treated with strong bases such sodium hydroxide $(\mathrm{NaOH})$ or, potash (KOH) they undergo saponification to form glycerol and soap (the salt of the long chain fatty acid) (Bettelheim 2004)

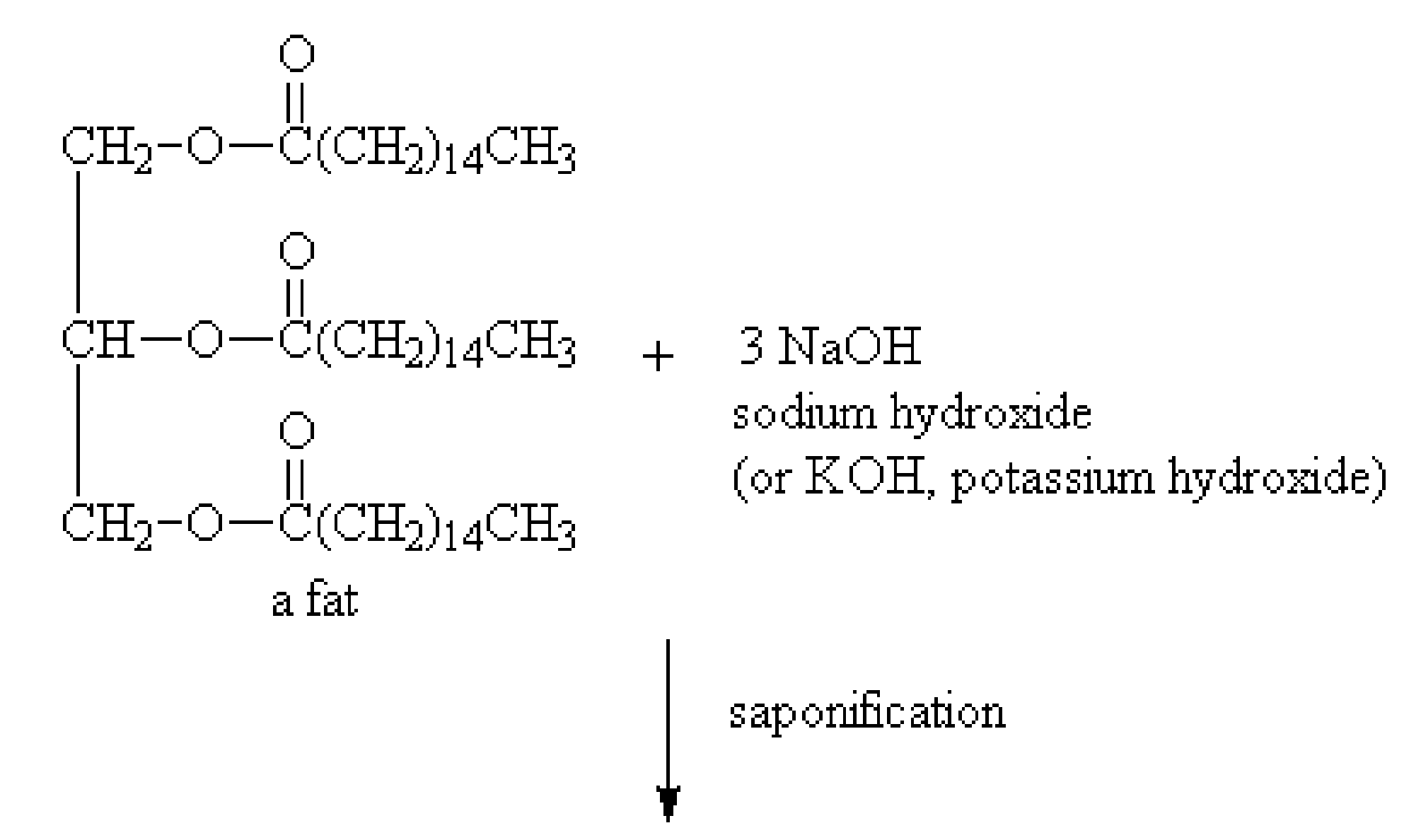

$$
\begin{aligned}
& \begin{array}{l}
\mathrm{CH}_{2}-\mathrm{OH} \\
\mathrm{CH}-\mathrm{OH}
\end{array}+3 \mathrm{CH}_{3}\left(\mathrm{CH}_{2}\right) 14 \mathrm{CO}_{2} \mathrm{Na} \\
& \underset{\mathrm{CH}}{\mathrm{CH}-\mathrm{OH}}+3 \mathrm{CH}_{3}\left(\mathrm{CH}_{2}\right) \mathrm{HCO}_{2} \\
& \text { glycerol } \\
& \text { a crude soap }
\end{aligned}
$$

Table 1. Titration Results
\begin{tabular}{|l|l|l|l|l|l|l|l|}
\hline & Initial HCl & Final HCl & Total & $\begin{array}{l}\text { Weight } \\
\text { NaOH }\end{array}$ & $\begin{array}{l}\text { Weight } \\
\text { KOH }\end{array}$ & $\begin{array}{l}\text { Moles } \\
\text { NaOH }\end{array}$ & Moles KOH \\
\hline $\begin{array}{l}\text { Wood ash } \\
\text { solution }\end{array}$ & $0.00 \mathrm{ml}$ & $5.5 \mathrm{ml}$ & $5.5 \mathrm{ml}$ & 0.029 & $0.03 \mathrm{~g}$ & $5,5 \times 10^{\wedge-4}$ & $5.6 \times 10^{\wedge}-4$ \\
\hline IPCT data & & & & $0.003 \mathrm{~g}$ & $0.03 \mathrm{~g}$ & & \\
\hline $\begin{array}{l}\text { Banana ash } \\
\text { solution }\end{array}$ & $5.5 \mathrm{ml}$ & $12.0 \mathrm{ml}$ & $6.5 \mathrm{ml}$ & 0.039 & 0.049 & $6.5 \times 10^{\wedge-4}$ & $6.7 \times 10^{\wedge}-4$ \\
\hline & $12.0 \mathrm{ml}$ & $18.4 \mathrm{ml}$ & $6.4 \mathrm{ml}$ & & & & \\
\hline
\end{tabular}

Tablet shows the titration results of $1 \mathrm{~g}$ of banana ashes and wood ashes dissolved in $100 \mathrm{ml} \mathrm{O}$
distilled water and titrated against $0.1 \mathrm{M} \mathrm{HCl}$ by using three drops of phenolphlated. The $0.02 \mathrm{~g}$ $\mathrm{NaOH}$ and $0.03 \mathrm{KOH}$ in wood ashes based on calculation assuming all the base comes from data for $\% \mathrm{Na}$ and $\% \mathrm{~K}+.003 \mathrm{NaOH}$ and $0.03 \mathrm{KOH}$ in the same ash are based on ICPC

\section{PREPARATION OF FATS \& OILS}

Cut the fat from meat and wash it with clean cold water. Cut it in small pieces and place it in cooking
pan with water to fill the pans/4 full. Boil it until the water evaporates, then reduce the heat and

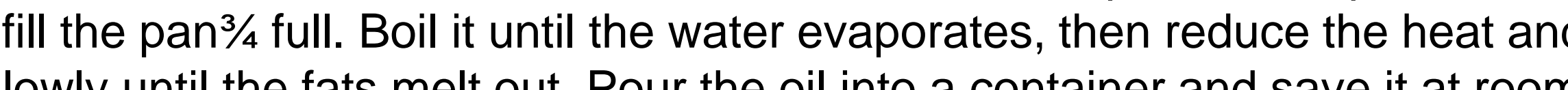
temperature for several weeks before using it to make soap. Another methods; fry the bacon in the (20.7) Pressure extraction separates oil from the solid particles by squeezing the oil out of the crushed of the seeds. Some oils need to be pressed out mechanically. Filter the oil to remove particles from
the pressing operation and save the oil.

\section{PREPARATION OF SOAP USING LABORATORY PROTOCAL}

$12 \mathrm{gs}$ sodium hydroxide dissolved in $50 \mathrm{ml}$ water and $50 \mathrm{ml}$ of $95 \%$ ethanol. The solution was mixed with
25 g of shortening and heated for 45 minutes in a boiling water bath 50.50 solutions of thathel and water was added in portion in the mixture and stirred occasionally. Atter heating the soap solution was poured into a solution of $125 \mathrm{~d}$ sodium chloride in $375 \mathrm{ml}$ of water. The soap was isolated by vacuum Iftration using a buchner funnel from the combined reaction mixture and sodium chloride solution. The PREPARATION OF SOAP USING FAT ISOLATED IN COOKING

$12 \mathrm{~g}$ of sodium hydroxide dissolved in $30 \mathrm{ml}$ of water and warmed to $50 \mathrm{C}$. The solution was mixed with s.
several weeks. Soap from vegetable ails and ash-extract alkali use the same procedure as above.

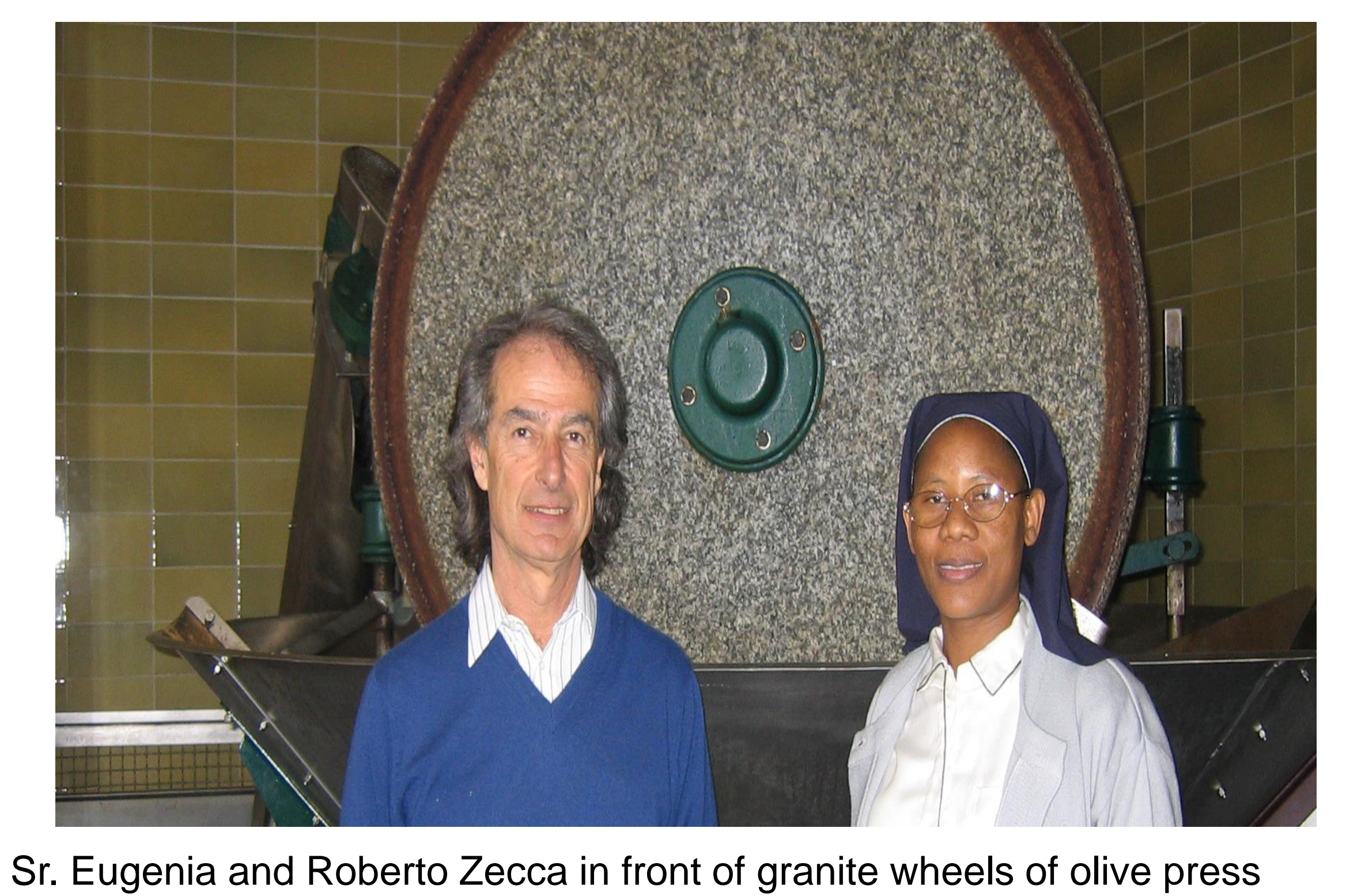

Table 2. Data for Soap Samples

\begin{tabular}{|l|l|l|l|}
\hline Foam Test & pH & $\begin{array}{l}\text { \# of Test } \\
\text { Tube }\end{array}$ & Lather \\
\hline Dove soap (Control) & 7 & 7 & Strong \\
\hline Soap made from beef fat & 7 & 11 & Very strong \\
\hline Soap made from corn oil & 7 & 12 & Strong \\
\hline Soap made from bacon fat & 7 & 8 & strong \\
\hline Soap made from cotton seeds oil & 8 & 9 & Strong \\
\hline Soap made from shortening & 8.5 & 1 & Medium \\
\hline Soap made from banana ash solution\& shortening & 9 & 4 & Nothing formed \\
\hline Soap made from wood ash \& bacon fat & 9 & 3 & Nothing formed \\
\hline
\end{tabular}

Table 2 shows the end point of soaps made from different
fats and oils. The pH of soaps made from $100 \mathrm{~g}$ of beet, bacon fat and corn oil with $12 \mathrm{~g} \mathrm{NaOH}$ have same $\mathrm{pH}$ as higher pH. No fort
extract alkali.

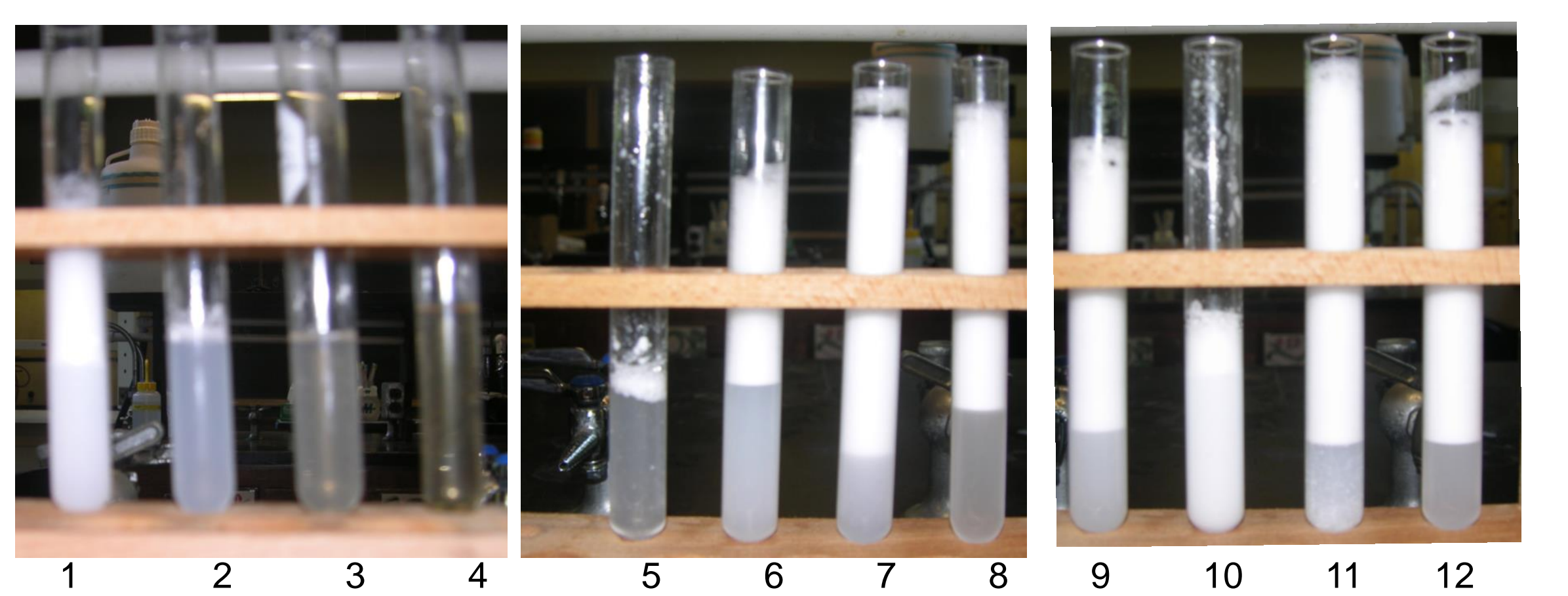

DISCUSSION

The soap produced using $50 \%$ sodium hydroxide solution was hard and gave the most foam in our
foam test. The ash alkali soap had a harder consistency - The difference in harness between the foam test. The ash alkali soap had a harder consistency. The difference in harness between the
pure sodium hydroxide and the ash-extract soap could be accounted for the presence of other metallic ions in the ashes. The toan abilly or he pure sodium hydroxide soap was very different trom that of the ash-extract

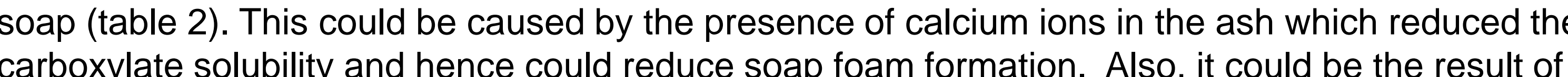
low concentralion of extracted alkall, which was not as effective as the pure sodium hydroxide. fats and vegh the fats and vegetable oils. By using Dove soap as a control, the results give the possibility of that,
soaps were made in this project could be safe on human skin. The infrared spectra show absorbances typical of alkali metal carboxylates.

SOAP RECIPE

Ingredients For a Tradtional Animal Fat Soap (For example if you want to make a one bar

of soap)
$100 \mathrm{~g}$ of $\mathrm{fat}$

(

$30 \mathrm{ml}$ of distilled water or rainwater
Instruction Add the NaOH in the water, mixing careful untili dissolved. Heat the lye
solution to $50 \mathrm{C}$ on a stove. Melt the fat in a saucepana nand bring it to $50 \mathrm{C}$ on the stove

Blend the lye solution into the fat, stirring clockwise. Maintain the temperature about $45 \mathrm{C}$

to $50 \mathrm{C}$ and stir for 45 minutes or until the soap shows tracing. Then pour it into a clean
mould and leave to set for 2 days. Then release it from the mould and leave it to cure for

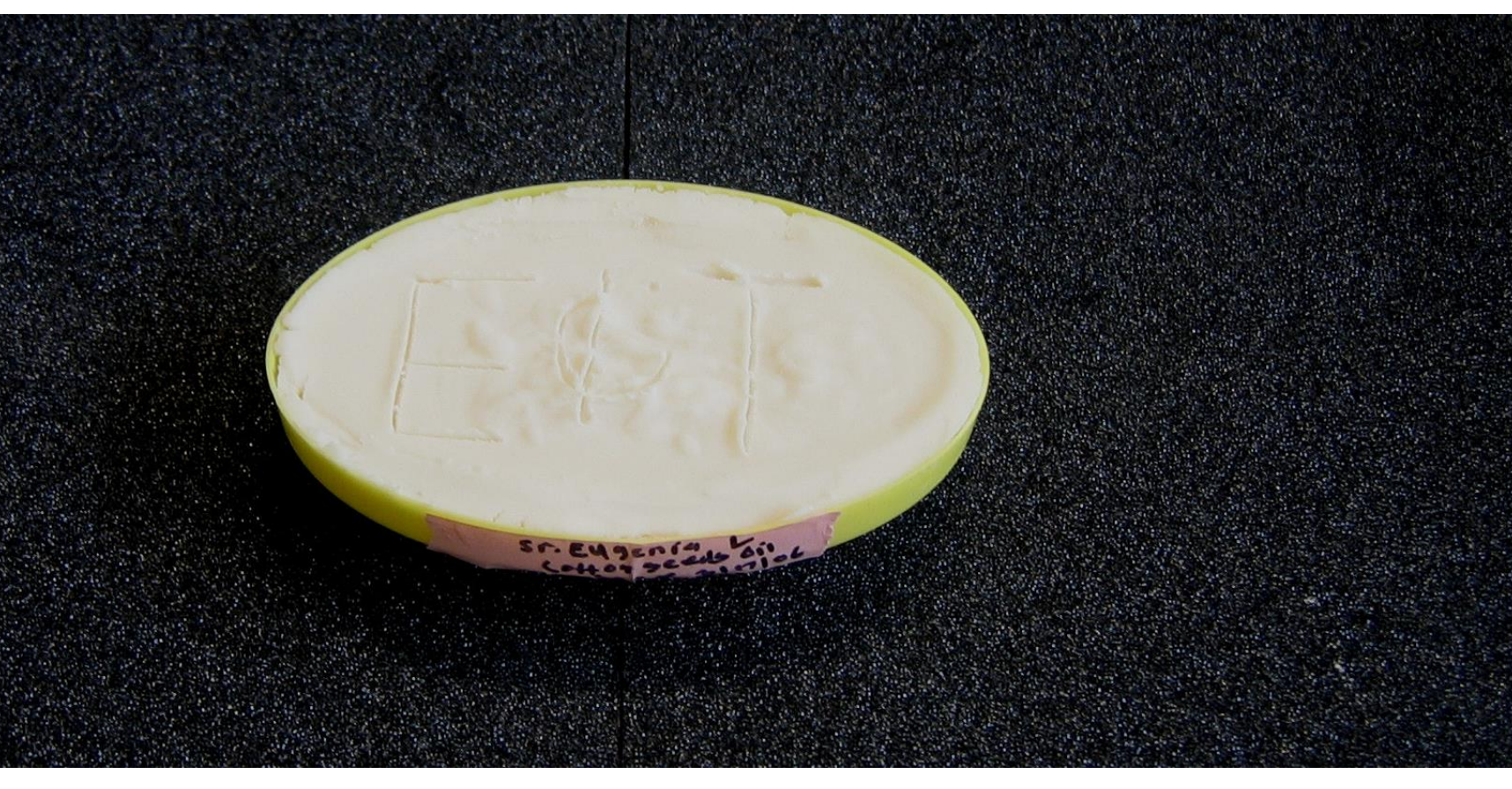

UPISHI WA SABUNI

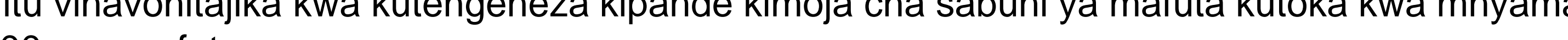
$2 \mathrm{~g}$ za tindikali ( $\mathrm{NaOH}$ ) au $18 \mathrm{~g} \mathrm{za} \mathrm{KOH}$

$30 \mathrm{ml}$ za maji ya mvua

Pima kivango cha maii kama ilivohapo juu Pima kiasi cha tindikali na kichanganye kwenye maii. Koronga tindikali iyeyuke kwenye maji na kisha upashe moto ule mchanganyiko hadi kipimo cha joto kitikie 50
aapashe moto matuta kwa kiasi kile kile cha joto. Kwa utaratibu mimina tindikali kwenye mafutat huku

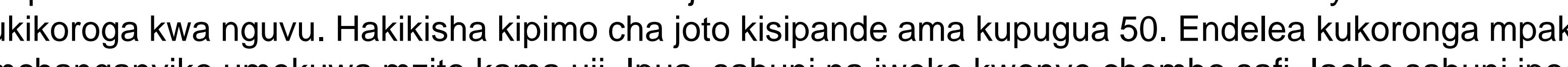
mchanganyiko umekuwa mzito kama uji. Ipua sabuni na iweke kwenye chombo safi. lache sabuni ipoe
kwa muda wa siku mbili hivi na baadae unaweza kuitoa kwenye chombo na itakuwa tayari kutumika baada ya majuma $3-5$

CONCLUSIOI

The soap made from pure sodium hydroxide with animal fat extracted in the kitchen, corn oil, and cottonseed oil was good and acceptable for household use.

More studd ys needed tor the alkal derived from plantain peels ashes because the resultant soap was
not effective as soap made from pure sodium hydroxide. 